\title{
Container Terminal Land-Utilisation Efficiency in Ghana
}

\author{
George Kobina vanDyck ${ }^{1}$, Stephen Anokye Domfeh ${ }^{2}$, George Konney ${ }^{3}$ \\ ${ }^{1}$ Regional Maritime University, Accra, Ghana \\ ${ }^{2}$ Maritime Initiative Africa, Tema, Ghana \\ ${ }^{3}$ Ghana Ports and Harbours Authority, Tema, Ghana \\ Email: vandyck.george@rmu.edu.gh, ohenestephen440@gmail.com, george.konney@gpha.net
}

How to cite this paper: vanDyck, G.K., Domfeh, S.A. and Konney, G. (2020) Container Terminal Land-Utilisation Efficiency in Ghana. Journal of Transportation Technologies, 10, 1-15.

https://doi.org/10.4236/jtts.2020.101001

Received: September 5, 2019

Accepted: December 9, 2019

Published: December 12, 2019

Copyright $\odot 2020$ by author(s) and Scientific Research Publishing Inc. This work is licensed under the Creative Commons Attribution International License (CC BY 4.0).

http://creativecommons.org/licenses/by/4.0/

Open Access

\begin{abstract}
Land-use efficiency is essential in ports, in particular those that are constrained for space and experiencing congestion. In such situations, ports have been noted to invest in off-dock container yards. This study analysed land use efficiency of four off-dock yards located near the Port of Tema, Ghana's largest seaport responsible for 85 percent of its trade. The study found that the terminals utilised 0.13 to 0.52 hectares of land, largely influenced by the dwell time and stacking height of containers. It was recommended that regulatory agencies need to coordinate better to reduce the time spent on cargo inspection and validation. In addition, terminals may need to incentivise customers to clear their import containers within shorter periods.
\end{abstract}

\section{Keywords}

Land Utilisation, Container Terminal, Off Dock Yard, Ghana, Efficiency, Dwell Time

\section{Introduction}

The dynamics of world trade requires ports today to ensure faster turnaround time of modern ships. This has greatly increased the pressure on ports around the world [1] to make huge investments in infrastructure and superstructure to accommodate such requirements. Ports have also had to streamline operations to ensure that limited port space is used efficiently.

Essentially, port lands are limited for competing interests and port authorities are faced with the daunting task of identifying the facilities and activities that will not only increase their competitive advantage, but also maximize port revenue. Increasing demands on terminal facilities and other port infrastructure cre- 
ated by changing port services now compel port authorities all over the world to plan, develop, and administer lands in port areas to ensure efficiency.

On a micro-level, land requirements for port container terminals have changed because of the need for both short and long-term storage areas, larger berths able to accommodate larger vessels, and cargo capacity and characteristics. This therefore calls for the adoption of efficient land use planning methods by port authorities and subsequently, efficient land use by terminal operators within port enclaves.

The Port of Tema, the larger of the two ports in Ghana is located about 30 kilometres $(30 \mathrm{~km})$ east of Accra, the capital city [2]. The port stretches over a land area of 3.9 million square metres [3]. In 2017, the port handled 1557 vessels with a total cargo traffic of about 14 million metric tonnes [4]. Container traffic for 2017 was 956,347 TEUs.

In essence, 85 percent of Ghana's trade is done through the port, which also serves the landlocked countries of Burkina Faso, Mali and Niger. The port handled about 1 million metric tonnes of transit cargo meant for the landlocked region in 2017, a very significant increase of 21 percent over 2016 levels (862,377 metric tonnes). The role of the Port of Tema in supporting trade between West Africa and the rest of the world cannot be overstated, and how its land is put to use is therefore of concern to major stakeholders. The Port of Tema is constrained for space [2] and although an expansion project is being undertaken with expected increases in inflows of cargoes, there has been little assessment of how efficiently lands allocated for container terminals are utilised in port areas. Sea ports in developing countries rake in substantial amounts in revenues and therefore have significant positive economic and social impacts. Efficiency of land utilisation of container terminals is essential for the overall growth and development of ports.

The main objective of the study is to analyse the relative efficiency of land utilisation among key off-dock container terminals at the Port of Tema. To the best of the authors' knowledge, no study has been undertaken to determine land efficiency levels of off-dock terminals in Tema. The study further recommends some strategies and options for optimizing efficiency of land utilization to contribute to the overall efficiency of the port.

\section{Port Development to Meet Growing Demand}

It is undisputable that ports play a decisive role in economic development in coastal African countries. In the past, the African continent was known for its under-developed artificial ports [5] [6]. Ports often received throughput far in excess of their capacity limits and capacity shortfalls were often reported for most sub-Saharan coastal nations [7]. Unfortunately, this phenomenon still exists today. This is partly due to the fact that there has been significant rise in incomes in the region which has resulted in an increase in the demand for shipping and subsequently port use. Despite this, port capacity and logistics have not 
scaled up with the increasing traffic across most parts of Africa, causing severe challenges to sea ports especially with regards to congestion [8].

Shipping remains by far the most common mode of international freight transport and is the backbone to facilitating international trade, offering the most economical and reliable way to move goods over long distances. For ships to carry large volumes of goods, significant infrastructure investments at seaports is required as the lack of appropriate infrastructure and superstructure can adversely affect the efficiency of port operations.

Within the last decade, African ports have seen an increase in investments and are beginning to see marginal improvements in their scale and operational efficiency. There is a catalogue of significant investments from foreign governments (predominantly China) and state-owned enterprises, and Private Public Partnerships (PPPs) with global terminal operators from all over the world. For example, investments by the French company, Bolloré, in Pointe Noire in the Democratic Republic of Congo increased the port capacity substantially and significantly improved the port's service offering by extending services to other parts of the Central African region. Ports in many parts of Africa are going through similar reforms aimed at increasing capacity and performance. Growth in the volume of West Africa's container trade, for instance, has doubled to almost 5 million TEUs, exceeding that of any other region globally [9].

\section{Container Terminals}

To function efficiently and to maximize its potential, a port needs two types of assets; the physical infrastructure and superstructure facilities for loading and unloading, and the administrative and customs services necessary to facilitate the transit of goods; in addition to supporting information and communication technologies (ICT). The overall efficiency of a port therefore depends directly on the quality of both its physical and administrative infrastructure, as well as the institutional framework [8]. One important physical asset is the container terminal which has a direct impact on the efficiency and level of port services.

A container terminal may be described as an open area on the berth where vessels are anchored to allow containers to be loaded/unloaded and transported to a storage yard. Containers may be stuffed and unstuffed, maintained, stored, or loaded or unloaded from one mode of transport to another-that is, vessel, truck, barge, or rail [10].

Reference [11] also defined the operational functions of container terminals to include the activities of facilitating the arrival and departure of vessels, providing navigational aids and vessel traffic system facilities, pilotage, towing and mooring activities, use of berths, sheds, etc., loading, discharging, storage and distribution of cargo. Therefore, container terminal operations can be said to involve all activities associated with a container box until the box is "gated-out" from the terminal either loaded or empty. Physically, a container terminal may compose of a harbour entrance, one or more quays, a large yard surface suitably organized 
in sectors by a regular layout, and road network for movement [12]. Reference [13] noted that container terminals play an important role in logistics networks and have to be efficient intermodal nodes.

In a situation where a port is constrained for space or is experiencing congestion, it may decide to invest in off-dock terminals (usually referred to as container yards) or an Inland Container Depot (also known as a dry port). For the latter, they are located in the hinterland of a country and are presumed an extension of a port. They may engage in the full complement of port activities including customs inspection. Therefore, an importer/exporter will not need to go to the coastal region to access port services. This study however focuses on off-dock container yards/terminals.

An off-dock container yard may be described as an area designated by a carrier to receive, store and deliver laden and unladen containers. According to reference [14], containers are stored in container yards prior to loading on a ship in the case of exports and after unloading from a ship in the case of imports. For imports, it is not unusual for containers to be received at an intermediate location prior to movement to a container yard and they may be moved to a designated yard or staging area before being loaded onto trucks for onward delivery.

The status of containers in a container yard determines the storage strategies that will be applied. For import containers, they are usually discharged from vessels in large batches and retrieved by individual customers in small numbers. The retrieval time is unknown, but is often related to the arrival time. For export containers, their arrival time is often unknown but the retrieval time is relatively fixed by the retrieving vessels. In the case of transhipment containers, both arrival and retrieval time are relatively fixed [15]. The strategy chosen should best utilize information on incoming containers for proper container location analysis and operations.

\section{Port Land Use and Land Utilization of Container Terminals}

According to [16], ports face difficult choices on expansion of facilities. Alternative choices for facility expansion include increasing land efficiency of existing terminals (in order to maximize capacity), developing greenfields or expanding into brownfields. Reference [17] considers the problem of high traffic and land scarcity in container ports. The authors propose a framework that integrates reservation of space and assignment of workloads and the results of the study show that the proposal is viable. Reference [18] examines land-use efficiency of ten United States ports in comparison to the port of Singapore. The study found that the ports under study in the United States were at least four times less efficient than the Port of Singapore.

Generally, the productivity of a container terminal is influenced by a range of factors which can be categorised into two; internal and external factors [19]. Internal factors are those that are usually under the control of the terminal includ- 
ing the terminal layout, investment in resources and the productivity of labour. External factors are those outside the realm of the terminal's control and include the trade volumes of the port, ship calls and the number of import and export containers (ultimately influencing the number of empty containers handled at the terminal) [20]. For instance, in Ghana, some container terminals are specifically dedicated to certain types of containerised cargo, regardless of the shipper's preference with regards to location, service levels or costs. Therefore, the throughput of the terminal is highly influenced by the types of goods located in the container.

The need for port authorities to enhance capacity to meet growing demands by pure physical expansion is constrained by scarcity of land, especially for ports located in urban city areas. In such restrictive circumstances, the capacity of ports can be expanded by improving the productivity of terminal facilities. The efficient use of available ground slots relates to the number of containers stacked in a given area of the terminal. Improving the utilization of ground slots typically reduces the operational accessibility to containers [18]; that is, there is an inverse relation between ground space utilization and container accessibility [20]. The challenge is therefore to define container accessibility in relation to ground space utilization based on a terminal's operational targets and unique physical characteristics.

\subsection{Factors That Affect Land Utilization Efficiency of Container Terminals}

There are several factors that affect container terminal land utilisation. They include the Container Dwell Time (CDT), Stacking Height (SH) and Container Handling System (CHS).

\subsubsection{Container Dwell Time}

Container dwell time is a measure of the time from which a container is unloaded from a ship until it leaves the container yard to its final destination. This mostly applies to import containers. For export containers, the reverse is true and is therefore a measure of time from when a container arrives at the container yard until it is loaded on-board a ship. CDT may be influenced by several factors such as gate operations, availability and efficiency of hinterland connections and customs regulations. The shipper can be identified as one of the key stakeholders who determine the CDT, as when to pick-up import containers or to deliver export containers rests with the shipper.

Container dwell time is a critical indicator of the efficient use of terminal area. In most cases, there are other factors such as customs and importers commercial practices for which the terminal operator has no control over. Generally, the acceptable global levels for container dwell time are 2 days for exports and 7 days for imports [21]. Historically, it has been established that the stacking area needed in a container yard is linearly proportional to the average container dwell time in a container terminal [22]. The dwell time translates into the number of 
Total Ground Slots (TGS) required for stacking a certain throughput in a container yard, which further influences the land area required for a given throughput.

\subsubsection{Stacking Height}

Increasing traffic in ports has basically increased the demand for storage space by both port users and operators. Increasing container traffic in addition to storage yard capacity constraints have created quite complex operational challenges for port operators in providing efficient services [23]. The common practice in situations like this to make use of vertical space by stacking and storing containers to multi-levels. However, [17] argued that the practice of multi-level stacking of containers in storage yards may cause unproductive handling and repositioning of containers, and a high concentration of activities in a small area. This may in turn result in traffic congestion from container transporters if activities within the storage yard are not properly and efficiently coordinated.

Reference [24] distinguished the two types of stacking strategies namely Category Stacking and Residence Time Stacking. The category stacking strategy assumes that containers of the same category or common features (size, destination, weight, etc.) are interchangeable. Due to these common features, they can be stacked on top of each other without the risk of a lower container in a stack being needed before ones on top have been removed. Residence time stacking on the other hand takes into account the departure times of the containers. This strategy therefore ensures that a container can only be stacked on top of containers that all have a planned departure time that is later than that particular container's departure time.

There are several factors that cause variation in stacking height of containers in a terminal. The most important factors include dimensions, type and status of containers, and type of container handling equipment. The stacking height affects the total ground slots which in turn maximize the utilization of available container yard land.

- Dimensions of Containers-Loaded 20-footer containers in general can be stacked higher than 40 -footer containers because of the difficulty in handling large boxes at a higher height. Moreover, due to the weight of such containers (40-foot), high stacking might be too heavy for the yard surface.

- Type of Containers-Containers such as hazardous, refrigerated and other special containers that require some special handling affect the height at which the container can be stacked. The stacking height is affected here because there may be few "special" containers in the terminal and as result high stacking may cause handling challenges. In addition, some containers that carry cargoes that are "out-of-gauge" will not be stackable on standard boxes in the terminal due to the heterogeneous nature of the container types.

- Status of Containers-Depending on the cargo type (imports, exports or empties), the stacking height will vary. For instance, with imported cargoes, stacking will not be too high to avoid difficult handling because these cargoes 
usually have a short stay at the terminal. When containers are export cargoes, stacking can be high and accessibility will not be a problem since all containers stacked in a particular area may be loaded on board vessels within the same period of time. For empties, containers can be staked higher than laden ones because of the reduced weight restrictions.

- Equipment used in the terminal-The height of the stacked containers depends on the type of the terminal equipment being utilised. Each type of equipment has a standard stacking height and as result the stacking height of containers in the terminal cannot go beyond what the equipment can handle.

\subsubsection{Container Handling System}

The container handling system includes the equipment required to receive, manoeuvre, and dispatch standardized containers at the terminal. The type of container handling system is a function of the type of equipment used which in practice determines the stacking height of containers in a terminal. Therefore, the type of equipment used in a container terminal is a major determinant of land utilization efficiency of the terminal.

The most common container terminal handling equipment used around the world is Reach Stackers. This is because of their advantage of flexibility and higher stacking and storage capacity when compared to lift trucks. Generally, containers can be stacked up to 5-high by using reach stackers. Aisles between container blocks can also be kept narrower than with lift trucks, thus improving space utilization. Operator's visibility is enhanced improving safety [25]. Brinkmann (2011) compliments the benefits of reach stackers by indicating that due to their versatility in operation, reach stackers are often the best choice for small and medium size container terminals and for multi-purpose terminals.

For large terminals that handle smaller throughput, the Chassis or truck-trailer container handling system is commonly used. This system is predominantly used in North America. With the chassis handling system, containers are stored on regular road chassis in the yard. Terminal tractors move containers on chassis between the ship-to-shore cranes and the container yard [25]. The truck-trailer system enables higher operational efficiency in terms of cargo handling but has a deficiency of poor land utilization efficiency. Other equipment used in terminals include but are not limited to Straddle Carrier, Rail/Tyre mounted Gantry Crane, and Automatic Stacking Crane.

Assuming an equal balance between imports and exports, [26] citing [27] expresses the level of land utilisation per handling system (Table 1).

Table 1. Container handling system versus land utilisation.

\begin{tabular}{cccccc}
\hline $\begin{array}{c}\text { System } \\
\text { |Feature }\end{array}$ & $\begin{array}{c}\text { Tractor/chassis } \\
\text { System }\end{array}$ & $\begin{array}{c}\text { Straddle Carrier } \\
\text { Direct System }\end{array}$ & $\begin{array}{c}\text { Straddle Carrier } \\
\text { Relay System }\end{array}$ & $\begin{array}{c}\text { Yard Gantry } \\
\text { Crane System }\end{array}$ & $\begin{array}{c}\text { Front-end Loader } \\
\text { System }\end{array}$ \\
\hline $\begin{array}{c}\text { Land } \\
\text { |Utilization }\end{array}$ & $\begin{array}{c}\text { Very poor: } \\
\text { 180 TEU/ha }\end{array}$ & $\begin{array}{c}\text { Good: } \\
385 \mathrm{TEU} / \mathrm{ha}\end{array}$ & $\begin{array}{c}\text { Good: } \\
\text { 385 TEU/ha }\end{array}$ & $\begin{array}{c}\text { Very Good: } \\
750 \mathrm{TEU} / \mathrm{ha}\end{array}$ & 275 TEU/ha \\
\hline
\end{tabular}

Source: Culled from [26]. 


\section{Container Terminals at the Port of Tema}

The statutory body responsible for building and operating ports in Ghana is the Ghana Ports and Harbours Authority (GPHA). GPHA has licensed several private terminal operators to operate off-dock container terminals that offer container receipt and delivery services. These private organisations include Tema Container Terminal (TCT), Tema Bonded Terminal (TBT), Maersk Container Terminal (MCT), Amaris Terminal (AT), Atlas Manufacturing and Engineering Services (AMES), African Coastal Services (ACS), and APM Terminal (APMT). There is however one state-owned terminal known as the Golden Jubilee Terminal (GJT). The study focuses on four private off-dock terminals.

The Port of Tema operates a container yard function, whereby containers are located both inside and outside the port. Off-dock container yards at Tema are located outside the main port enclave on leased lands that belong to the Port Authority. This was a strategic decision by the port as the yards are located about two kilometres from the port and allows for fast movement of containers between the port and the container yards. Containers are allowed to dwell in the in-port container yards for maximum of 3 days after which they a transferred to the appropriate off-dock yard until they are cleared by customs or released to the consignee [28]. Export containers are usually allocated to container yards within the port (although excess capacity is sent to off-dock terminals) whiles import containers are largely assigned to off-dock yards. The main purpose of the off-dock yards is to make the port more efficient by decongesting the port area and facilitating better port operations [29].

There are numerous processes for containerised cargo particularly with respect to customs clearance and this affects dwell time of container terminals. These include customs compliance, cargo inspection, cargo release and exit gate procedures. Regulatory bodies such as Environmental Protection Agency (EPA), Food and Drugs Authority (FDA), Narcotics Control Board (NCB), Ghana Atomic Energy Commission (GAEC) and Ghana Standards Authority (GSA) also inspect containerised cargoes at the various terminals depending on the type of cargo and the safety and/or security risk.

Upon ship arrival at the Port of Tema, containerized cargo is distributed based on three main criteria:

- Consignee's request for specific assignment. Consignees may request for their containers to be assigned to a specific container terminal through an official letter to the Port Authority. Upon agreement to the request by GPHA, the consignee or his/her agent must write a letter notifying the specified container terminal to expect the container, indicating the container number and any other relevant information for easy identification.

- Shipping line affiliation with container terminals. In such a scenario, the moment a vessel berths at the port, all containers for the port are unloaded to the affiliate terminal. Typical examples at the Port of Tema include Mediterranean Shipping Line's (MSC) affiliation with ACS terminal, and Maersk 
Line and Safmarine's affiliation with APMT. The latter is expected as AMPT is a subsidiary of AP Moller Maersk and as such all their cargoes are routed through APM Terminal.

- Type of Cargo. The type of cargo may in some instances influence which container terminal will receive the container. At the Port of Tema, containerized cargoes such as vehicles and personal effects are taken to the state-owned Golden Jubilee Terminal, whereas dangerous cargoes are taken to TBT (usually on temporary basis).

\section{Research Methodology}

Usually, with studies of this nature, obtaining reliable and consistent data is a challenge as terminal operators usually deem such information essential to their competitive advantage. As such, anonymity and confidentiality were important in this study to ensure that participating terminals would not be expressly identified and would participate in the study. For the purpose of anonymity; the terminals under study are designated T1, T2, T3 and T4. Data and information collected was provided by the container terminals. To express the capacity of container terminals in a uniform manner, TEUs were used for all iterations and subsequent analyses.

Following the work of [26], the following equations were used to ascertain the land utilisation efficiency of the off-dock terminals under study.

The land area is the actual space used to handle a terminal's throughput for a given period. It is represented by the formula:

$$
\text { Land Area }=\text { Total Ground Slots } * \text { Separation factor } * 15 \mathrm{~m}^{2}
$$

Whereby, the total ground slots (projected area of standard 20ft container) is calculated as:

$$
\text { Total Ground Slots }(\text { TGS })=\frac{\text { Daily Stacking Demand }(\text { Dsd }) * \text { Peaking Factor }}{\text { Stacking Height }}
$$

DSD is the average number of containers stacked per day at a terminal. DSD is represented by the formula:

$$
\mathrm{DSD}=\text { Throughput }(\text { per annum }) * \frac{\text { mean dwell time }}{365}
$$

The rule-of-thumb for the peaking factor, which is the contingency space plan, is usually twenty 20 or 30 percent of the daily stacking demand. The Peaking factor ranges from 1.1 to 1.5 , but is usually set at 1.3 [30]. This study, however, did not use the peaking factor because the objective is not to forecast the amount of space to make available, but to analyse the amount of space utilised.

The Stacking Height depends on the equipment/terminal management/handling system adopted and the category of throughput in question, i.e., whether the containers are imports, exports or empties.

The Parameter Reserve Factor, also known as the Separation Factor is usually a fifth or quarter (20 - 25 percent) of the total ground slots [31]. 
Mean Dwell Time $=\frac{\text { Import dwell Time }+ \text { Export dwell Time }}{2}$

Note: $15 \mathrm{~m}^{2}=$ Ground slot (space) for one TEU. All land areas are converted into hectares.

\section{Data and Analysis}

Computing the land area utilised based on the throughput for 2017, variables such as dwell time, throughput, total ground slots, stacking height, and other related measures have been used. For all terminals under study (Table 2), 20ft containers accounted for $68.2 \%$ of the total throughput the terminals handled. 92.9\% of $20 \mathrm{ft}$ containers were house-to-house cargoes, $3.9 \%$ were partial delivery cargoes while the remaining $3.1 \%$ were stripped cargoes. $40 \mathrm{ft}$ containers accounted for $31.7 \%$ of the total throughput handled. $86.8 \%$ of the $40 \mathrm{ft}$ containers were house-to-house cargoes, whiles partial deliveries accounted for $12.8 \%$ and stripped cargoes accounted for $0.39 \%$ of the total.

Table 2. Summary of Container Throughput of off-dock terminals under study.

\begin{tabular}{|c|c|c|c|c|}
\hline \multicolumn{5}{|c|}{$\mathrm{T} 1$} \\
\hline & $20 \mathrm{ft}$ & $40 \mathrm{ft}$ & Unit total & TEUs \\
\hline House-to-house & 26,073 & 8800 & 34,873 & 43,673 \\
\hline Partial deliveries & 542 & 993 & 1535 & 2528 \\
\hline Stripped & 870 & 53 & 923 & 976 \\
\hline Total & 27,485 & 9846 & 37,331 & 47,177 \\
\hline \multicolumn{5}{|c|}{$\mathrm{T} 2$} \\
\hline & $20 \mathrm{ft}$ & $40 \mathrm{ft}$ & Unit total & TEUs \\
\hline House-to-house & 20,776 & 7554 & 28,330 & 35,884 \\
\hline Partial deliveries & 365 & 495 & 860 & 1355 \\
\hline Stripped & 668 & 19 & 687 & 706 \\
\hline Total & 21,809 & 8068 & 29,877 & 37,945 \\
\hline \multicolumn{5}{|c|}{ T3 } \\
\hline & $20 \mathrm{ft}$ & $40 \mathrm{ft}$ & Unit total & TEUs \\
\hline House-to-house & 26,439 & 18,059 & 44,498 & 62,557 \\
\hline Partial deliveries & 2307 & 3388 & 5695 & 9083 \\
\hline Stripped & 240 & 71 & 311 & 382 \\
\hline Total & 28,986 & 21518 & 50,504 & 72,022 \\
\hline \multicolumn{5}{|c|}{$\mathrm{T} 4$} \\
\hline & $20 \mathrm{ft}$ & $40 \mathrm{ft}$ & Unit total & TEUs \\
\hline House-to-house & 11,627 & 2576 & 14,203 & 16,779 \\
\hline Partial deliveries & 384 & 571 & 955 & 1526 \\
\hline Stripped & 1085 & 24 & 1109 & 1133 \\
\hline Total & 13,096 & 3171 & 16,267 & 19,438 \\
\hline
\end{tabular}

Source: Terminal operators. 
Moreover, the container terminals handle $36.5 \%$ more $20 \mathrm{ft}$ containers than 40 $\mathrm{ft}$ containers. $61 \%$ of all $20 \mathrm{ft}$ containers are house-to-house cargoes, thus, the cargo moves from the shipper's premises to the consignee's premises or place of business. Most $20 \mathrm{ft}$ containers are full container loads (FCLs), which usually belong to one consignee. This is due to the lot sizes of the consignments, weight restrictions and the cost associated with the container type. House-to-house containers accounted for $90 \%$ of all containers handled by the off-dock terminals, partial deliveries $8 \%$ and stripped containers accounted for $2 \%$. About $60 \%$ of partial delivery cargoes (unstuffed at the terminal) were stored in $40 \mathrm{ft}$ containers. Most $40 \mathrm{ft}$ containers were less-than container loads (LCLs) because they were mostly consolidated cargoes. This increases the lot size of consignments and the associated weight. About $70 \%$ of house-to-house cargoes and $94 \%$ of stripped cargoes were stored in $20 \mathrm{ft}$ containers (Figure 1).

Table 3 summarises the main key variables that impact the land utilisation efficiency of the terminals under study. T3 had the highest throughput with 72,022 TEUs in 2017 followed by T1, T2 and T4. T3 also utilised the highest stack of 5 containers with the best mean dwell time of 4.9 days. T1 however had the worst mean dwell time of 8.5 days which implies that containers spend an average of 8.5 days before they are cleared from the terminal. All terminals utilised reach stackers in their operations.

The study revealed that the land utilization efficiency among the terminals is largely influenced by the dwell time, the stacking height and the type of equipment used at the terminal. With shorter dwell time, space is created for the stacking of containers that arrive at the terminal. But with longer dwell time, the terminal will be required to create additional space for stacking incoming containers or will be unable to accept containers.

Table 3. Summary of computation variables and results.

\begin{tabular}{ccccc}
\hline \multirow{2}{*}{ Variables and Results } & \multicolumn{4}{c}{ Terminals } \\
\cline { 2 - 5 } & T1 & T2 & T3 & T4 \\
\hline Throughput (TEUs) & 47,177 & 37,945 & 72,022 & 19,438 \\
Equipment Type & Reach Stacker & Reach Stacker & Reach Stacker & Reach Stacker \\
Stacking Height (TEUs) & 4.00 & 4.00 & 5.00 & 4.00 \\
Import Dwell Time (Days) & 12.50 & 8.00 & 4.80 & 5.00 \\
Export Dwell Time (Days & 4.50 & 7.00 & 5.00 & 6.00 \\
Mean Dwell Time (Days) & 8.50 & 7.50 & 4.90 & 5.50 \\
Daily Stacking Demand (DSD) & 1099.00 & 780.00 & 967.00 & 293.00 \\
(15 m²/slot) & & & & 73.00 \\
Total Ground Slot (TGS) & 275.00 & 195.00 & 193.00 & 15.00 \\
Aisle Width (Metres) & 15.00 & 15.00 & 15.00 & 1.25 \\
Separation Factor & 1.25 & 1.25 & 1.25 & 0.14 \\
Land Utilization (Ha) & 0.52 & 0.37 & 0.36 &
\end{tabular}




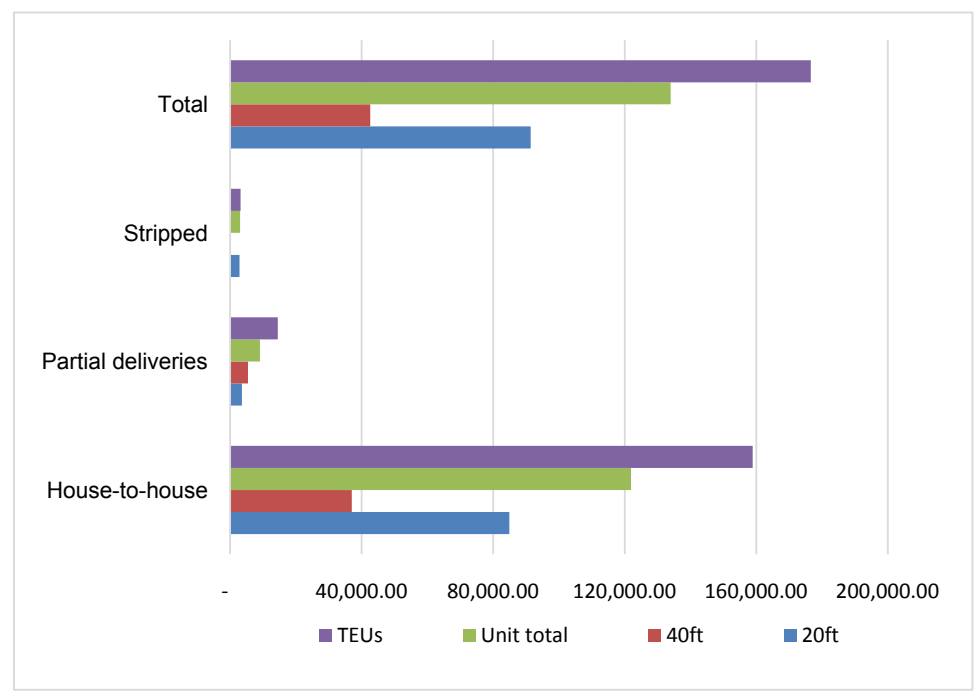

Figure 1. Off-dock terminal throughput breakdown.

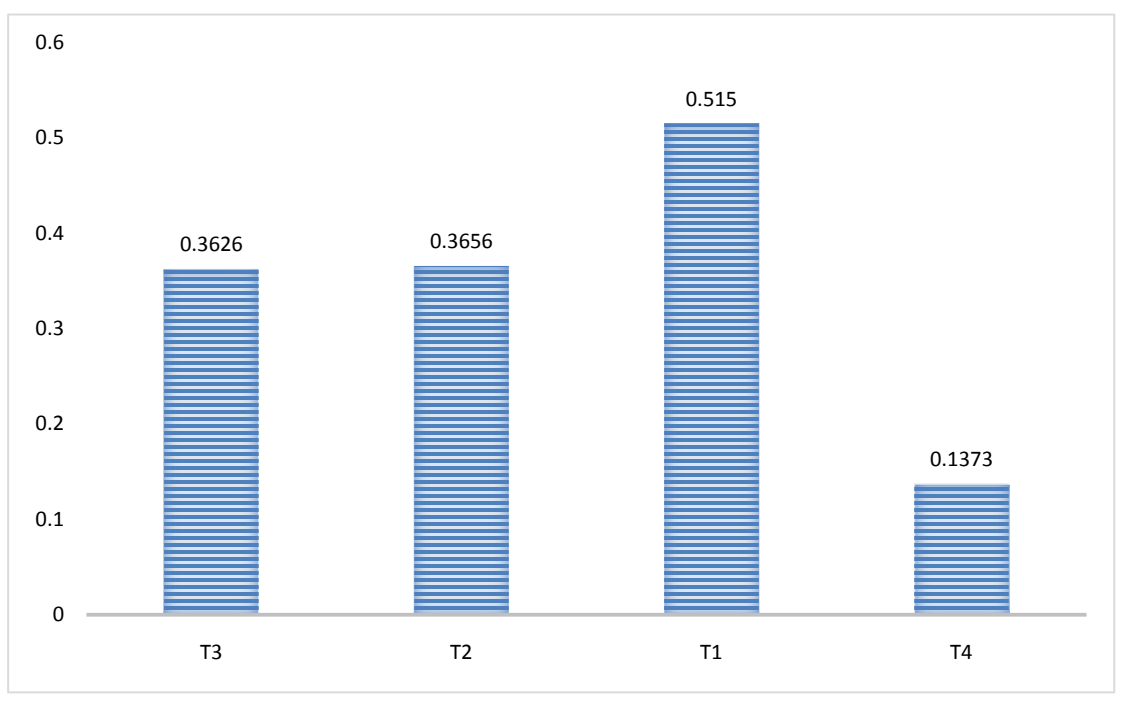

Figure 2. Land utilisation of terminals under study.

The study revealed that $\mathrm{T} 4$ was the most efficient terminal in terms of maximizing land utilization among the four terminals under study (Figure 2). T4 utilised 0.13 ha of land to handle a throughput of 19,438 TEUs. T4 had the second lowest dwell time of 5.5 days with a good stacking height of 4-high. T3 placed second and had the shortest dwell time of 4.9 days and the highest stacking height of 5-high. T3 also had the highest throughput of all terminals with 72,022 TEUs handled in 2017. T2 placed third by utilising 0.37 ha for a throughput of 37,945 in 2017. T1 place fourth with the worst average dwell time of 8.5 days amongst all terminals under study. T1 also utilised a stack of 4-high with a throughput of 47,177 TEUs in 2017.

One useful finding of the study was that the maximization of land utilized by T3 was also influenced by the dimension of the aisles (the space in between two container blocks where the reach stacker manoeuvres). All terminals under 
study used an aisle width of $15 \mathrm{~m}$. However, in peak periods, T3 shrinks the aisles to $12.5 \mathrm{~m}$ to create space for stacking additional containers while the others maintain the $15 \mathrm{~m}$ aisle dimension. Although reducing the aisle width increases the space utilisation, operational efficiency may be negatively affected due to the restrictive area for equipment manoeuvring. This also depends on the skills of the operator handling the equipment. The study further revealed that dwell time is affected by delays on the part of regulatory agencies with respect to certification of import and export cargoes. Delays are also experienced due to improper document processing and poor transport arrangements by importers and exporters.

\section{Main Findings and Conclusions}

The findings of the study indicated that T4 terminal was the most efficient terminal among the four terminals under study by utilising 0.13 ha of land to handle a throughput of 19,438 TEUs in 2017. This was largely as a result of the relatively short dwell time (5.5 days) and the stacking height (four-high). T4 had a dwell time of 5 days and 6 days for import and export containers respectively. T1 used the most land ( $0.52 \mathrm{ha}$ ) for a throughput of 47,177 TEUs (which was the second highest throughput). This was largely due to the mean dwell time of 8.5 days. In particular, the import dwell time of T1 was 12.5 days which is excessive for modern container terminals. However, their export dwell time was lowest at 4.5 days. T1 stacked an average of 1099 TEUs per day with a total throughput of 47,177 TEUs. To put this in context, with a throughput of 72,022, T3 stacked 967 TEUs per day. This goes further to prove that containers dwell too long at T1.

Dwell time and stacking height are the most significant factors affecting land utilisation efficiency. There are two significant ways that off-dock terminals can improve the efficiency of land-use. They are by reducing the dwell time of containers and increasing the stacking height. However, high stacking also affects operational efficiency. Dense and vertical stacking may become necessary if terminal capacity is constrained. As container throughput at the terminals increases, terminals could adopt handling systems that allow for further increase in stacking height such as Rail-mounted Gantry (RMG) and Rubber-tyre Gantry (RTG) systems. The use of RTG or RMG will reduce the aisle space between the container blocks, thereby increasing the amount of ground slots that will be available and ultimately improve the space utilization of the yard area.

Container dwell time can be improved at all terminals by improving processes regarding cargo inspection, certification and clearance. These however are external influences and will need concerted efforts by all stakeholders to reduce dwell times. Multiple agencies with interests in cargo need to coordinate better to reduce the time spent on cargo inspection and validation. Better coordination between terminals and their clients is also needed in order to improve the time taken to release cargoes. In some cases, containers are ready for dispatch but clients have not arranged for transportation of the containers. This may be due to lack of appropriate communication and a general apathetical attitude towards 
cargo clearance. Another strategy that can be deployed by terminals is to incentivise customers to clear their import containers as soon as possible. For example, providing discounts on handling charges for customers that are able to clear cargo within the standard period of 7 days.

Further research may be conducted on extending the study to all off-dock terminals located around the Port of Tema. In addition, it is important to determine the operational efficiencies of the off-dock terminals as they affect the competitiveness of the port as a whole. This will also expand the analysis on the impact of land utilisation efficiency on operational efficiency of terminals.

\section{Conflicts of Interest}

The authors declare no conflicts of interest regarding the publication of this paper.

\section{References}

[1] EPA (2016) Climate Change Indicators in the United States. Fourth Edition.

[2] De Jong, G. and Baas, T. (2015) Sector Report: Port Development in Ghana. https://www.rvo.nl

[3] UNEP (2017) Global Environmental Outlook: Regional Assessment for Africa. http://www.uneplive.org/media/docs/assessments/GEO_6_regional_assessment_for _africa_print_finallow_res.pdf

[4] GPHA (2018) Ghana Ports and Harbours Authority Port Performance. GPHA, Tema.

[5] UNCTAD (1999) African Transport Infrastructure, Trade and Competitiveness. UNCTAD, New York and Geneva.

[6] Wood, G. (2004) Tanzanian Coastal and Inland Ports and Shipping: Crises and Policy. Maritime Policy and Management, 31, 157-171. https://doi.org/10.1080/0308883042000205052

[7] Raballand, G., Refas, S., Beuran, M. and Isik, G. (2012) Why Does Cargo Spend Weeks in Sub-Saharan African Ports? World Bank, Washington DC. https://doi.org/10.1596/978-0-8213-9499-1

[8] AFDB (2010) Ports, Logistics and Trade in Africa. Oxford University Press, New York.

[9] Streatfeild, J. (2018) West Africa Is Expanding Its Maritime Ports to Accommodate Growing Container Trade. USITC, Washington DC.

[10] Weintrit, A. and Neumann, T. (2013) Marine Navigation and Safety of Sea Transportation: Maritime Transport \& Shipping. CRC Press, Taylor \& Francis Group, Boca Raton. https://doi.org/10.1201/b14960

[11] Hiranandan, V. (2013) Port Operations and Management. https://www.slideshare.net/VijayHiranandani/port-operations-management-slidesh ow

[12] Legato, P., Gullì, D., Trunfio, R. and Simino, R. (2008) Simulation at a Maritime Container Terminal: Models and Computational Frameworks. 22nd European Conference on Modelling and SIM, Nicosia, 3-6 June 2008, 261-269. https://doi.org/10.7148/2008-0261

[13] Ambrosino, D. and Peirano, L. (2016) Truck Arrival Management at Maritime Container Terminals. 30th European Conference on Modelling and Simulation, 
New York, 31 May-3 June 2016, 114-120. https://doi.org/10.7148/2016-0114

[14] Manaadiar, H. (2014) What Is a Container Yard. https://shippingandfreightresource.com/what-is-cy-cy-term-in-container-shipping

[15] Zhen, L., Jiang, X., Lee, L. and Chew, E. (2013) A Review on Yard Management in Container Terminals. Industrial Engineering \& Management Systems, 12, 289-305. https://doi.org/10.7232/iems.2013.12.4.289

[16] United States Environmental Protection Agency (2019) Land Use. https://www.epa.gov/community-port-collaboration-and-capacity-building/ports-p rimer-52-land-use

[17] Jiang, X., Lee, L.H., Chew, E.P., Han, Y. and Tan, K.C. (2012) A Container Yard Storage Strategy for Improving Land Utilization and Operation Efficiency in a Transshipment Hub Port. European Journal of Operational Research, 221, 64-73. https://doi.org/10.1016/j.ejor.2012.03.011

[18] NRDC (2004) Port Land-Use Efficiency Methodology: Harbouring Pollution, Strategies to Clean up US Ports. https://www.nrdc.org/sites/default/files/ports_app.pdf

[19] Dowd, T. and Leschine, T. (1990) Container Terminal Productivity: A Perspective. Maritime Policy \& Management, 17, 107-112. https://doi.org/10.1080/03088839000000060

[20] Le-Griffin, H. and Murphy, M. (2006) Container Terminal Productivity: Experiences at the Porta of Los Angeles and Long Beach.

[21] Marc, H. (2017) Container Terminal Concession Guidelines. The World Bank Group, Washington DC.

[22] Little, J. (1961) A Proof of the Formula L= $\lambda \mathrm{W}$. Operations Research, 9, 383-387. https://doi.org/10.1287/opre.9.3.383

[23] Carlos, H., Vis, I. and Roodbergen, K. (2014) Storage Yard Operations in Container Terminals: Literature Overview, Trends, and Research Directions. European Journal of Operational Research, 235, 412-430. https://doi.org/10.1016/j.ejor.2013.10.054

[24] Dekker, R., Voogd, P. and van Asperen, E. (2006) Advanced Methods for Container Stacking. OR Spectrum, 28, 563-586. https://doi.org/10.1007/s00291-006-0038-3

[25] Kalmar Industries (2010) Kalmar Container Handling Systems. http://www.portmizer.com/download/Container\%20Handling\%20Systems\%20broc hure.pdf

[26] Zheng, S. (2015) Port Enterprise Management. Container Terminal Planning.

[27] UNCTAD (1986) Container Terminal Development: Improving Port Performance. United Nations, Geneva.

[28] GHPA (2010) Port Performance. GHPA-Press, Tema-Ghana.

[29] Quashigah, J. (2011) Inland Container Terminals: Role and Contribution to Decongestion of the Port of Tema. http://erl.rmu.edu.gh:8080/xmlui/bitstream/handle/123456789/43/QUASHIGAH\% 2C\%20Julius\%20\%282011\%29.pdf? sequence=1\&isAllowed $=y$

[30] Balliere, N., Chun, I., Jin Kil, J. and Korbaa, O. (2006) Comparison of Various Indicators for Measuring Operational Performance of Container Terminals. (Illustrative Case: Busan Port). Journal of Korean Society of Coastal and Ocean Engineers, 18, 35-42.

[31] Kourounioti, I., Polydoropoulou, A. and Tsiklidis, C. (2015) Development of a Methodological Framework for the Dwell Time of Containers in Marine Terminals: First Results. 